\title{
Evaluation of Rural Tourism Carrying Capacity Based on Ecological Footprint Model
}

\author{
Lei Li ${ }^{1},{ }^{1}$ Xiaojuan Ye, ${ }^{1}$ and Xilong Wang ${ }^{2}$ \\ ${ }^{1}$ College of Tourism, Xinyang Normal University, Xinyang 464000, Henan, China \\ ${ }^{2}$ College of Management, Ocean University of China, Qingdao 266100, Shandong, China
}

Correspondence should be addressed to Lei Li; 2020261709@xynu.edu.cn

Received 27 December 2021; Revised 19 January 2022; Accepted 27 January 2022; Published 17 February 2022

Academic Editor: Nima Jafari Navimipour

Copyright (c) 2022 Lei Li et al. This is an open access article distributed under the Creative Commons Attribution License, which permits unrestricted use, distribution, and reproduction in any medium, provided the original work is properly cited.

\begin{abstract}
The evaluation of the environmental carrying capacity of tourism resources has important guiding significance for the sustainable development of tourism. This study uses the ecological footprint index to construct the evaluation model of rural tourism environmental carrying capacity and quantitatively analyzes the impact of rural tourism ecological footprint on the environment, ecological pressure, and the maximum carrying capacity of tourists in Nanyang City (China) from 2011 to 2020, so as to provide a reference basis for local rural tourism planning and ecological environment management. The empirical analysis results show that (1) during the decade 2011-2020, the overall ecological footprint increased by $31.47 \%$; however, the per capita ecological footprint showed a downward trend year by year; (2) in the ten years from 2011 to 2020, although the environmental carrying capacity was in surplus, it showed a downward trend year by year, and the ecological pressure index initially appeared; (3) taking the number of tourists in 2020 as the reference value, the prediction of the ecological pressure of rural tourism environment and the carrying capacity of tourists shows that although the ecological pressure is in a relatively safe state, it will show an unsafe state with the increase of the number of tourists. Based on the above results, it is suggested that local governments and tourism planning and management departments should pay full attention to the adverse impact of tourism development on the environment, strengthen the construction of green transportation, balance the development of tourism resources, scientifically control the number of tourists, improve tourists' awareness of environmental protection, protect the ecological environment of Nanyang City, and realize the sustainable development of rural tourism.
\end{abstract}

\section{Introduction}

Tourism is the main way of relaxation and entertainment for modern people. Because of its beautiful natural scenery, strong local flavor, and rich folk culture, rural tourism is sought after by tourists all over the world. With the vigorous development of rural tourism, some scenic spots or tourist destinations operate in the pursuit of short-term interests, saturated or super environment carrying capacity, and it leads to the destruction of ecological environment, the decline in the humanistic environment, the waste of social resources, and the decline of tourists' satisfaction, which seriously affects the long-term and stable development of rural tourism. With the popularization of the concept of sustainable development, in order to realize the sustainable development of the tourism environment, the carrying capacity of tourism resources and environment has become one of the criteria to judge the sustainable development of tourism [1] and the focus of rural tourism research. Therefore, it is of great significance to evaluate the environmental carrying capacity of the rural tourism accurately and ensure its operation within the carrying capacity range to ensure the healthy and long-term development of the rural tourism.

Henan Province is a major agricultural province in China. It carries about $8 \%$ of the population (994 million people) with $1.7 \%$ of the land (167000 square kilometers). It is rich in tourism resources, but more than $70 \%$ of the tourism resources are located in rural areas. Therefore, the effective utilization and economical development of tourism resources have become the key factors for the sustainable development of rural tourism. The size of resource carrying 
capacity can evaluate the current situation of rural tourism development and put forward theoretical suggestions for rural tourism development [2]. In recent years, Nanyang City, Henan Province, has vigorously developed rural tourism projects and has formed more than 30 special tourism villages and rural tourism demonstration sites [3], and more than 15,300 rural tourism business units, which have strongly contributed to local economic growth [4]. At present, the operation and management mode of the tourism industry gradually presents the development trend of information. In order to adapt to the development of the contemporary information society, the rural tourism industry should gradually implement the information construction of its own industry. However, with the rapid development of tourism, the impact on the environment has become increasingly severe, which is not conducive to the sustainable development of rural tourism in Nanyang City. The evaluation of tourism environmental carrying capacity is an important tool to ensure the rational planning and effective management of scenic spots [5]. Therefore, this study applies the ecological footprint index to construct an evaluation model of the environmental carrying capacity of rural tourism in Nanyang City and quantifies and analyzes the impact of the ecological footprint of rural tourism on the environment, ecological pressure, and the maximum carrying capacity of the number of tourists during the ten years from 2011 to 2020, in order to provide a reference for its next rural tourism planning and ecological and environmental management (Figure 1).

\section{Literature Review}

In recent years, with the deterioration of the ecological environment caused by tourism in China becoming more and more prominent, the harmonious development of tourism and ecological environment has become one of the hot spots of academic research, and measuring the specific impact of tourism activities on ecological environment has undoubtedly become an important reference for formulating relevant countermeasures. In this regard, the ecological footprint theory proposed by Wackernagel and Rees is currently recognized as an effective means to measure the environmental carrying capacity at home and abroad [6]. This theory believes that the development and expansion of economies are limited by the environmental carrying capacity, so human consumption must consider the limits of ecological capacity [7]. Wackernagel further points out that the ecological footprint is proportional to the size of the environmental impact, the larger the ecological footprint, the greater the impact on the environment, and in addition, it is also inversely proportional to the area of biologically productive land available per person [8].

After the theory was proposed, it has been widely used by domestic and foreign scholars in the evaluation of various ecotourism cases. For example, the Lausanne School of Management in Switzerland uses it as an indicator for evaluating the competitiveness of environmental infrastructure. Meanwhile, the Global Environmental Sustainability Indicators published by the European Union
Research Centre also use it as a basis for assessing waste and consumption pressure. In addition, Wackernagel evaluates the state of the ecological footprint of tourism globally based on the ecological footprint theory [9].

Ecological footprint theory has also been further developed and expanded in China [10]. For example, Zhang Bo used the ARIMA model to carry out the prediction of the carrying capacity of ecological footprint indicators in Gansu Province [11]. Zhu Xinling used a neural network model to calculate the total ecological footprint of Wuhan city [12]. Yang Yimin used the ecological footprint model to study the sustainable development level [13] of the tourism industry in Zhangjiajie. Zhang Zhihong calculated the ecological footprint index of tourism in three cities of Guangxi [14].

In summary, it can be seen that domestic and foreign scholars' research on ecological footprint mostly focuses on the composition, influencing factors, and measurement models of tourism environmental carrying capacity, but the research results on the current trend of tourism ecological footprint, ecological safety, and tourist carrying capacity still need further improvement. In view of this, this paper constructs a rural tourism environmental carrying capacity evaluation model by quantitatively analyzing the impact of rural tourism ecological footprint on the environment, ecological pressure, and the maximum carrying capacity of the number of tourists during the decade of 2011-2020 in Nanyang City, with a view to providing concrete supporting evidence for the research innovation and practical application of ecological footprint theory.

\section{Carrying Capacity Evaluation of Rural Tourism Based on Ecological Footprint Model}

3.1. Model Construction. This study incorporated transportation, accommodation, tourism activities, and food and fiber consumption into the analysis framework, constructed an environmental carrying capacity evaluation model for rural tourism, and quantified and analyzed the impact of the ecological footprint of rural tourism on the environment, ecological pressure, and the maximum number of tourists during the decade 2011-2020 in Nanyang City with reference to the tourism ecological footprint calculation method proposed by Martin and Sanchez. The ecological footprint of rural tourism in Nanyang City from 2011 to 2020 was quantified and analyzed. The evaluation model is shown in Figure 2.

The model includes three parts as follows: ecological footprint, ecological carrying capacity, and ecological security. The calculation part of the model refers to the ecological footprint calculation method proposed [15] by Martin and Sanchez. By calculating the ecological footprint of rural tourism in Nanyang City from 2011 to 2020, the ecological footprint of transportation, accommodation, tourism activities, food, and fiber consumption and the corresponding ecological footprint of agricultural land, forest, grassland, water, and built-up land are calculated. The 


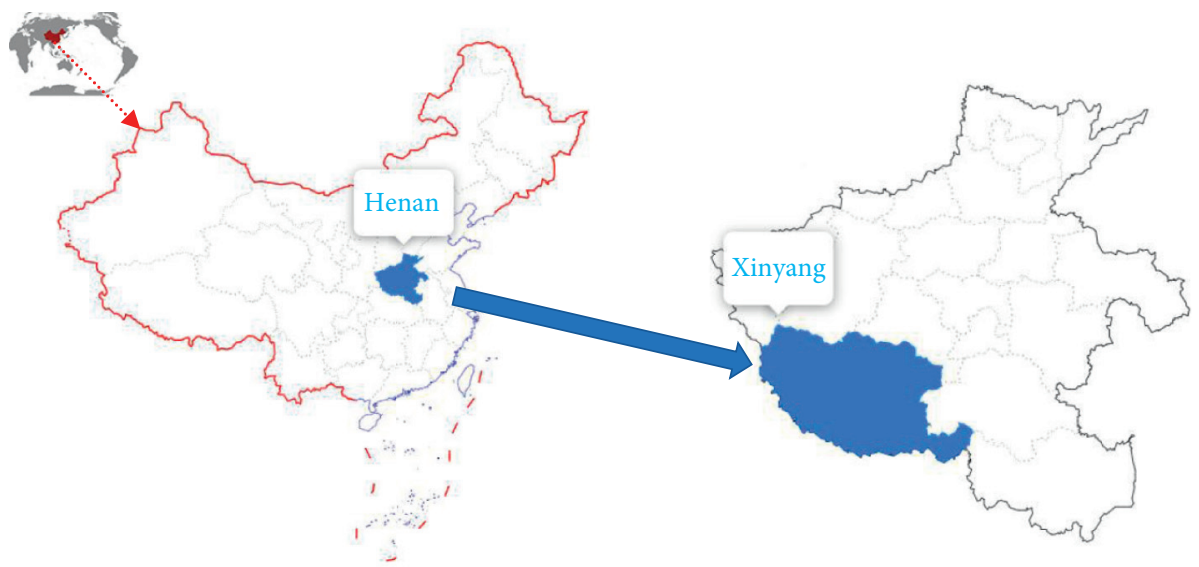

(a) The position of Henan Province in China

(b) Location of Nanyang City in Henan Province

Figure 1: Geographical location map of Nanyang City.

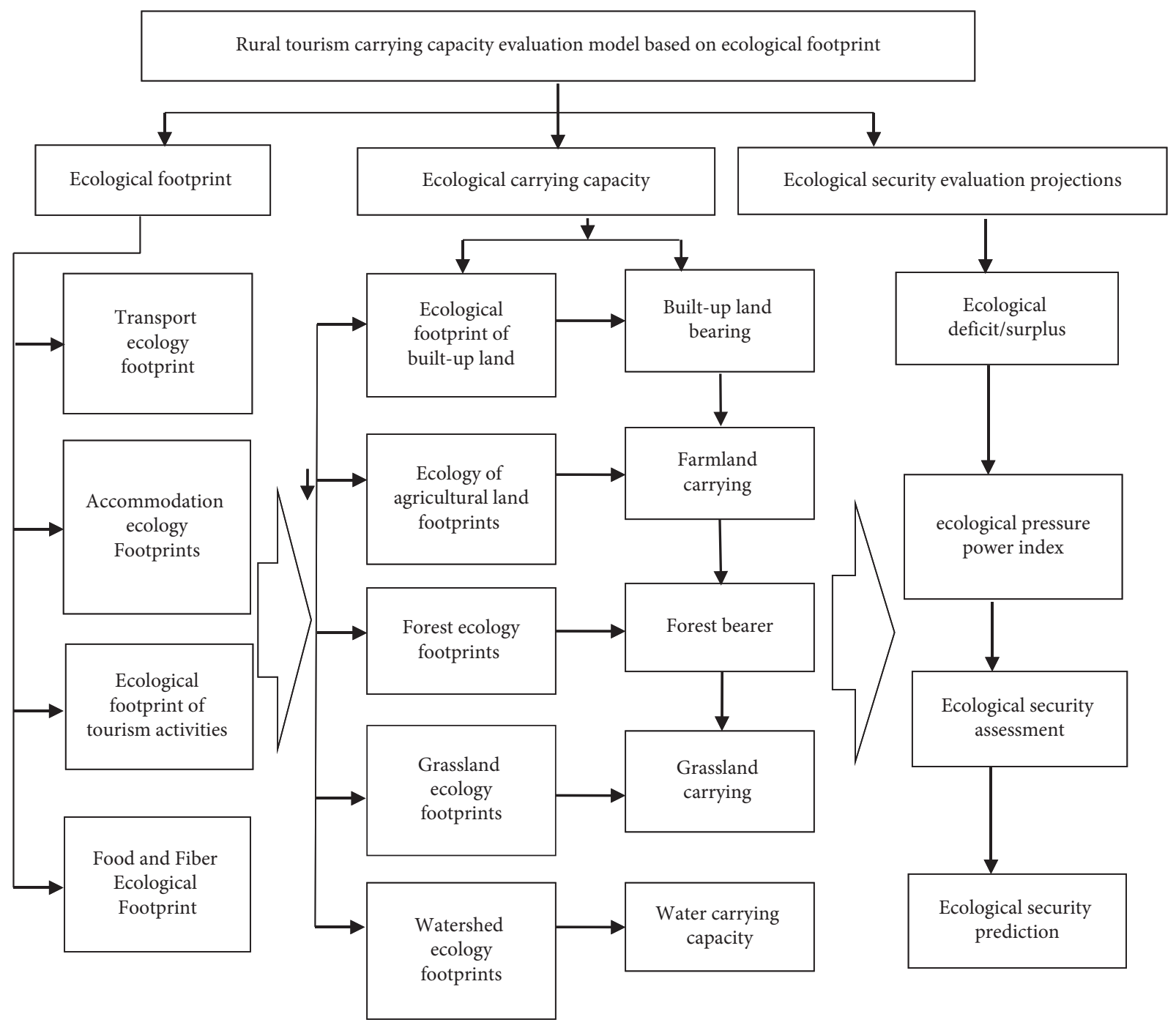

FIGURE 2: Evaluation model framework of rural tourism carrying capacity based on ecological footprint.

ecological footprint of rural tourism in Nanyang City is calculated by calculating the ecological footprint of transportation, accommodation, tourism activities, food, and fiber consumption and the corresponding ecological footprint of agricultural land, forest, grassland, water, and builtup land from 2011 to 2020. 
3.2. Data Sources. Research data from Nanyang (China) statistical yearbooks 2010-2020, Nanyang municipal people's government public website of the economic and social statistics (https://www.henan.gov.cn/2018/05-22/390850. html), and Nanyang land, rural tourism statistics released tourism management department. Because some data are incomplete or not available, the calculation is carried out in a hypothetical way. Statistics show that Nanyang covers a total area of 26,600 square kilometers and has a population of 11.94 million. In recent ten years, Nanyang City attaches great importance of the development of tourism, based on the rich ecological resources, cultural tourism resources, to build an internationally renowned ecological and cultural tourism destination as the goal, the development of rural tourism as an important part of the implementation of the development of all-for-one tourism. There are 40 national A-level scenic spots, including $25 \mathrm{~A}$-levels scenic spots and 18 4A-level scenic spots. There are 83 star-rated hotels, including 1 five-star hotel and 10 four-star hotels. There are 105 travel agencies, more than 60 demonstration sites for characteristic tourism and rural tourism, and more than 1,300 operating units for rural tourism. There are 3 national model villages for rural tourism, 3 national model families for rural tourism, and 30 national rural tourism farmhouses.

\subsection{Calculation Method}

\subsubsection{Methodology for Calculating the Ecological Footprint}

(1) Calculation of the Ecological Footprint of Transport. The transport ecological footprint (TEF) is the sum of the transport built-up footprint (TEFBU) and the transport carbon footprint (TEFCU). The transport ecological footprint calculation method in this study refers to Martin-Cejas and Sanchez's (2010) method for calculating the ecological footprint of tourism traffic. Traffic volume, type of transport, the fuel efficiency of transport, and road network are included in the calculation. The calculation formula is shown in equation as follows:

$$
\sum \mathrm{TEF}_{\mathrm{CU}} \times P i \times 2 D i \times \frac{\sum(V i j \times E I j)}{51} \times E Q F_{F L},
$$

where $P i: i$ is the number of regional visitors, $D i: i$ is the average mileage of Nanyang City, $V i j: i$ is the number of visitors in Nanyang City, and $j$ is the percentage of using transportation to the scenic spot. $E I j: i$ is the intensity of transportation. The calculation results are shown in Table 1.

(2) Calculation of the Ecological Footprint of Accommodation. Accommodation facilities are one of the necessary conditions for tourism activities. The ecological footprint of accommodation includes the following four categories: hotels, guest houses, inns, and B\&Bs. They are equipped with internal facilities such as parking spaces, plazas, restaurants, and recreational areas. The Ecological Footprint of Accommodation (ACCEF) is made up of two main productivity land categories: the Ecological Footprint of Built-up Accommodation (ACCEFBU) and the Carbon Footprint of
Accommodation (ACCEFCU). The calculation of the accommodation carbon footprint (ACCEFCU) is most directly evaluated in terms of the electricity consumption generated by each type of accommodation. Since specific electricity usage data are not easily available, this study calculates the carbon footprint of accommodation based on the average number of kWh of electricity consumed per night by accommodation beds, converted to carbon emissions from energy consumption.

$$
\begin{aligned}
\mathrm{ACCEF}_{\mathrm{CU}} & \times \mathrm{Room} \times \mathrm{Room}_{\mathrm{EN}} \div 3.6 \times 0.625 \\
& \div 1000 \div 3.6666 \times \mathrm{EQF}_{\mathrm{EN}} .
\end{aligned}
$$

In this equation, Room is the number of bed occupancy in the dwelling for that year. Room $\mathrm{EN}_{\text {is }}$ the energy consumption per bed night for that dwelling class.

(3) Calculation of the Ecological Footprint of Tourism. The ecological footprint of tourism activities (ACTEF) refers to the area of public facilities required by tourists to carry out various tourism activities in tourist destinations, which belongs to the category of built-up land in productive land, and therefore, ACTEF is the footprint of built-up land for tourism activities (ACTEFBU). In this paper, the land and areas within Nanyang City are defined into five categories: four types of recreation areas, historical preservation areas, special landscape areas, and ecological protection areas. After summing up the four types of areas and obtaining the weighted land area according to formula (3), the ecological footprint of tourism (ACTEF) from 2011 to 2020 can be measured, as shown in Table 2.

$$
\mathrm{ACTEF}=\text { Area }_{\mathrm{ACTBU}} \times \mathrm{YF}_{\mathrm{CL}} \times \mathrm{EQF}_{\mathrm{CL}} .
$$

(4) Ecological Footprint of Food and Fiber Consumption. The assessment of the ecological footprint of food and fiber consumption (FEF) is divided into two main components: food consumption and fiber consumption. The former of which the productive land corresponding to the resource consumption of tourists visitors in terms of food is agricultural land, grazing land, and fishing grounds; the latter of which is the demand of tourists for fiber products. Since information on food consumption in Nanyang City is not easily available, this study refers to the method of Gossling et al. to calculate the ecological footprint [16]. Assuming that the food and fiber consumption of tourists in Nanyang City is consistent with that of the average domestic household, the average annual productivity (average yield, $\mathrm{AY}_{i}$ ) of the food item can be obtained by dividing the calendar year domestic food production $\left(P_{i}\right)$ by the productive land area $\left(A_{i}\right)$ (equation (4)) and then multiplying the i-th food consumption by the equilibrium of the productivity land category corresponding to the $\mathrm{i}$-th food item, respectively. The $\mathrm{EQF}_{i}$ and $\mathrm{YF}_{i}$ factors were then divided by the average productivity of the productive land for food item $i\left(\mathrm{AY}_{i}\right)$ and converted to the ecological footprint of food and fiber consumption (FEF) (equation (5)). The forest production in a calendar year was then divided by the population and 365 days a year to obtain the daily per capita forest product 
TABLE 1: Ecological footprint of transportation in Nanyang City, 2011-2020 (unit: gha).

\begin{tabular}{lcccc}
\hline Year & Transportation built-up footprint $\left(\mathrm{TEF}_{\mathrm{BU}}\right)$ & $\begin{array}{c}\text { Transport carbon } \\
\text { footprint }\left(\mathrm{TEF}_{\mathrm{CU}}\right)\end{array}$ & $\begin{array}{c}\text { Transport ecological } \\
\text { footprint (TEF) }\end{array}$ & $\begin{array}{c}\text { Transportation ecology per capita } \\
\text { footprints }(\mathrm{PTEF})\end{array}$ \\
\hline 2011 & 5482.54 & 11070.85 & 16553.39 & 0.018372 \\
2012 & 5482.54 & 10286.17 & 15768.71 & 0.018372 \\
2013 & 5482.54 & 12076.60 & 17559.14 & 0.016011 \\
2014 & 5482.54 & 17479.73 & 22962.27 & 0.013187 \\
2015 & 5482.54 & 20125.69 & 25608.23 & 0.012709 \\
2016 & 5482.77 & 17587.89 & 23070.65 & 0.013031 \\
2017 & 5482.77 & 17390.58 & 22873.35 & 0.012995 \\
2018 & 5482.77 & 22063.01 & 27545.78 & 0.012268 \\
2019 & 5482.77 & 27896.90 & 33379.67 & 0.011693 \\
2020 & 5482.77 & 27936.72 & 33419.49 & 0.011624 \\
\hline
\end{tabular}

TABle 2: Ecological footprint of tourism activities in Nanyang City, 2011-2020.

\begin{tabular}{cccc}
\hline Year & Recreation centre area (ha) & Ecological footprint of tourism (gha) & Ecological footprint of tourism per capita (gha per capita) \\
\hline 2011 & 7520 & 18819.980 & 0.0208 \\
2012 & 9520 & 18819.980 & 0.0219 \\
2013 & 12120 & 11892.380 & 0.0108 \\
2014 & 13120 & 11892.380 & 0.0068 \\
2015 & 14120 & 11892.380 & 0.0059 \\
2016 & 14120 & 11892.380 & 0.0067 \\
2017 & 14120 & 11892.380 & 0.0067 \\
2018 & 14120 & 11892.380 & 0.0052 \\
2019 & 19390 & 11892.380 & 0.0041 \\
2020 & 19390 & 11892.380 & 0.0041 \\
\hline
\end{tabular}

consumption and then multiplied by the number of visitors, and finally, the consumption was converted into an ecological footprint using the equilibrium factor of forest land (EQFFL). The calculation is shown in equations (4)-(6).

$$
\begin{aligned}
\mathrm{AY}_{i}= & P_{i} \div A_{i}, \quad i=1,2, \cdots, 8, \\
\mathrm{FEF}= & \sum C_{\text {food }} \times \mathrm{EQF}_{i} \times \mathrm{YF}_{i} \div \mathrm{AY}_{i}, \quad i=1,2, \ldots, 8, \\
\mathrm{FEF}_{\mathrm{FL}}= & \text { Pop } \text { total } \div 365 \times \text { Pop }_{\text {tourist }} \\
& \div \text { Global TimberYield } \times \mathrm{EQF}_{\mathrm{FL}} .
\end{aligned}
$$

3.3.2. Analysis of the Carrying Capacity of the Tourism Environment. Natural resources of rural tourism can be broadly classified into productive and unproductive categories: productive resources can be used as agricultural land, building land, etc. and unproductive resources are mostly special landscape, ecological, environmentally sensitive, and unsuitable for development and use. This study refers to the environmental carrying capacity calculation method of Monfreda et al. and calculates the environmental carrying capacity of tourism in the formula area according to the land category [17]. The calculation formula is shown in equation as follows:

\section{Tourism carrying capacity}

$$
=\left\{\begin{array}{l}
\text { Agricultural land area } \times \text { agricultural land yield factor } \times \text { agricultural land equilibrium factor } \\
\quad=\text { biological carrying capacity of agricultural land } \\
\text { Grassland area } \times \text { Grassland yield factor } \times \text { Grassland equilibrium factor }=\text { Grassland biological carrying capacity } \\
\text { Forest area } \times \text { forest yield factor } \times \text { forest equilibrium factor }=\text { forest biological carrying capacity } \\
\text { Watershed area } \times \text { watershed yield factor } \times \text { watershed equilibrium factor }=\text { watershed biological carrying capacity } \\
\text { Built }- \text { up area } \times \text { built }- \text { up yield factor } \times \text { built }- \text { up equilibrium factor }=\text { built }- \text { up biological carrying capacity } \\
\text { Carbon sequestration area } \times \text { carbon sequestration yield factor } \times \text { carbon sequestration equilibrium factor } \\
\quad=\text { carbon sequestration biocarrying capacity. }
\end{array}\right.
$$

In this case, the conversion factors for carbon-sequestering land in the environmental carrying capacity calculation are the equilibrium factor for forests (EQFFL) and the yield factor (YFFL) for its multiplication. According to the assumptions of 
Monfreda et al. for anthropogenic structures and public facilities, the land is usually originally available for agricultural use. Therefore, the calculation is multiplied by the equilibrium (EQFCL) and yield factors (YFCL) of the agricultural land.

3.3.3. Calculation of Ecological Deficit/Surplus Status. Using the ecological footprint method, the environmental carrying capacity (BC) on the supply side of environmental resources in Nanyang City is subtracted from the ecological footprint $(\mathrm{EF})$ on the demand side of environmental resources, and if the value is greater than zero, it is called an ecological surplus; conversely, it is an ecological deficit. The calculation formula is shown in equation as follows:

$$
\mathrm{BC}-\mathrm{EF} \text {. }
$$

3.3.4. Ecological Stress Index (EFI) and Visitor Number Carrying Capacity Projections. Ecological stress index (EFI) refers to the ecological footprint per unit ecological carrying area of a region. In order to find the ecological footprint on the unit carrying area can better reflect the pressure on the ecological environment, this study uses the ecological pressure index (EFI) to evaluate the regional ecological security, using the number of tourists in 2020 as a control standard to predict the trend of ecological pressure changes due to the increase in the number of tourists in the future, the critical value of the carrying capacity of the number of tourists. The calculation formula is shown in equation as follows:

$$
\mathrm{EFI}=\frac{\mathrm{EF}}{\mathrm{BC}},
$$

where EFI is the ecological pressure index; EF is the ecological footprint; $\mathrm{BC}$ is the environmental carrying capacity. Because $\mathrm{EF}>0$ and $\mathrm{BC}>\mathrm{O}$, when $0<\mathrm{EFI}<1, \mathrm{EF}<\mathrm{BC}$, the supply and demand of ecological resources reach a balance, and the region is in a critical state of ecological security. when $\mathrm{EFI}=1, \mathrm{EF}=\mathrm{BC}$, ecological resources supply and demand reach balance, the region is in a critical state of ecological security; when $\mathrm{EFI}>1, \mathrm{EF}>\mathrm{BC}$, the unit ecological bearing. When EFI $>1, E F>B C$, the pressure per unit of ecological carrying area is greater than the supporting capacity it can provide, the supply and demand are unbalanced, and ecological security is threatened, and the greater the difference between EFI and 1, the greater the degree of ecological insecurity.

\subsection{Results and Analysis}

\subsubsection{Results of Ecological Footprint Calculation in Nanyang City}

(1) Transport Footprint of Nanyang City 2011-2020. Reference to Martin-Cejas and Sanchez's method for calculating the ecological footprint of tourism traffic, traffic volume, type of transport, fuel efficiency of transport, and road network are included in the calculation. The transportation footprint of Nanyang City from 2011 to 2020 was obtained as shown in Table 1.
As shown in the calculation results of Table 1 , the transportation built-up land footprint $\left(\mathrm{TEF}_{\mathrm{BU}}\right)$, transportation carbon footprint per capita (TEF $\mathrm{CU}$ ), and transportation ecological footprint per capita (TEF) all show an increasing trend year by year. The increase in the number of tourists has an important impact on the ecology of Nanyang City.

(2) Ecological Footprint of Accommodation in Nanyang City 2011-2020. The ecological footprint of accommodation in Nanyang City was calculated based on the average number of electricity consumption degrees per night of accommodation beds and converted into carbon emissions of energy consumption, as shown in Table 3.

As seen in Table 3, the trend in the carbon footprint of accommodation (ACCEFCU) is broadly in line with the builtup land. Visitor use of built-up land resources (ACCEFBU) for accommodation is low, increasing only from 5.535 gha to 13.369 gha from 2011 to 2020 , and there is a low peak in the accommodation built-up land footprint in 2020 .

(3) Ecological Footprint of Tourism Activities in Nanyang City, 2011-2020. The ecological footprint of tourism activities in Nanyang City between 2011 and 2020 (ACTEF) was measured by calculating the area of tourism area according to equation (3), and the ecological footprint of tourism activities between 2011 and 2020 was obtained, as shown in Table 2 .

Table 2 shows the change trend of tourism ecological footprint and per capita footprint of Nanyang city. The per capita tourism footprint decreases due to the increase in tourist arrivals, from 0.0208 gha in 2011 to 0.0041 gha in 2020 , a decrease of $80.20 \%$. This result reflects the dilution of the ecological footprint by the increase of tourists on the one hand and the improvement of the ecological environment in recent years on the other. (FEF)

4. Ecological footprint of food and fiber consumption

Calculated by equations (4)-(6), the ecological footprints of food and fiber consumption responses in the four land categories of agricultural land (FEFCL), grazing land (FEFGL), fishing land (FEFFG), and forest land (FEFFL) were obtained, respectively, for the calendar year, and the ecological footprints of food and fiber consumption (FEF) for each land category were summed to obtain the ecological footprint (FEF) for each land category, as shown in Table 4.

The food and fiber footprint responds to the amount of food and fiber consumed by tourists. As shown in Table 4, the overall food and fiber footprint of rural tourism has been increasing year by year in the last decade, from 729.758 gha in 2011 to 2310.246 gha in 2020 , with an average annual growth rate of $2.17 \%$. This shows that rural tourism in Nanyang City has shown a rapid development trend.

(5) Overall Ecological Footprint. Collating the ecological footprint data for the four tourism categories in Tables 1-4, the overall ecological footprint of rural tourism can be calculated as shown in Table 5 .

As shown in Table 5, the overall ecological footprint of rural tourism in Nanyang City increased from 
TABLE 3: Ecological footprint of accommodation in Nanyang City, 2011-2020 (unit: $\mathrm{hm}^{2}$ ).

\begin{tabular}{|c|c|c|c|c|}
\hline Year & $\begin{array}{l}\text { Accommodation built as eco-foot } \\
\text { signs (ACCEFBU) }\end{array}$ & $\begin{array}{l}\text { Accommodation carbon } \\
\text { footprint (ACCEFCU) }\end{array}$ & $\begin{array}{l}\text { Ecological footprint } \\
\text { of } \\
\text { accommodation } \\
\text { (ACCEF) }\end{array}$ & $\begin{array}{c}\text { Accommodation ecology per capita } \\
\text { footprints (PACCEF) }\end{array}$ \\
\hline 2011 & 5.535 & 514.574 & 520.109 & 0.000577 \\
\hline 2012 & 5.535 & 582.001 & 587.537 & 0.000685 \\
\hline 2013 & 5.535 & 479.087 & 484.622 & 0.0004 \\
\hline 2014 & 12.752 & 541.749 & 554.500 & 0.000318 \\
\hline 2015 & 12.752 & 546.106 & 558.857 & 0.000277 \\
\hline 2016 & 12.752 & 532.761 & 545.512 & 0.000308 \\
\hline 2017 & 12.907 & 488.882 & 501.790 & 0.0002 \\
\hline 2018 & 10.495 & 288.105 & 298.600 & 0.0001 \\
\hline 2019 & 13.369 & 442.619 & 455.988 & 0.000160 \\
\hline 2020 & 13.369 & 511.576 & 524.945 & 0.000183 \\
\hline
\end{tabular}

TABLE 4: Ecological footprint of food and fiber consumption in Nanyang City, 2011-2020.

\begin{tabular}{lcc}
\hline Year & $\begin{array}{c}\text { Food and fiber consumption raw } \\
\text { state footprint (gha) }\end{array}$ & $\begin{array}{c}\text { Ecology of food and fiber consumption } \\
\text { per capita footprints (gha per capita) }\end{array}$ \\
\hline 2011 & 729.758 & 0.0008 \\
2012 & 731.403 & 0.0008 \\
2013 & 1052.440 & 0.0009 \\
2014 & 1690.223 & 0.0009 \\
2015 & 1670.865 & 0.0008 \\
2016 & 1721.833 & 0.0009 \\
2017 & 1537.409 & 0.0008 \\
2018 & 1942.817 & 0.0008 \\
2019 & 2494.538 & 0.0008 \\
2020 & 2310.246 & 0.0008 \\
\hline
\end{tabular}

TABLE 5: Calculation results of the overall ecological footprint of Nanyang City from 2011 to 2020 (unit: gha).

\begin{tabular}{lcccccc}
\hline Year & $\begin{array}{c}\text { Transport ecology } \\
\text { footprinting }\end{array}$ & $\begin{array}{c}\text { Ecological footprint of } \\
\text { accommodation }\end{array}$ & $\begin{array}{c}\text { Leisure activities } \\
\text { ecological } \\
\text { footprint }\end{array}$ & $\begin{array}{c}\text { Food and fiber } \\
\text { ecological } \\
\text { footprint }\end{array}$ & $\begin{array}{c}\text { Overall life } \\
\text { footprint of a } \\
\text { state }\end{array}$ & $\begin{array}{c}\text { Overall per capita } \\
\text { ecological footprint }\end{array}$ \\
\hline 2011 & 16553.390 & 520.109 & 18819.980 & 729.758 & 36623.671 & 0.0406 \\
2012 & 15768.705 & 587.537 & 18819.980 & 731.403 & 35908.059 & 0.0418 \\
2013 & 17559.139 & 484.622 & 11892.380 & 1052.440 & 30989.015 & 0.0282 \\
2014 & 22962.266 & 554.500 & 11892.380 & 1690.223 & 37099.803 & 0.0213 \\
2015 & 25608.227 & 558.857 & 11892.380 & 1670.865 & 39730.763 & 0.0197 \\
2016 & 23070.653 & 545.512 & 11892.380 & 1721.833 & 37230.813 & 0.0210 \\
2017 & 22873.348 & 501.790 & 11892.380 & 1537.409 & 36805.434 & 0.0209 \\
2018 & 27545.781 & 298.600 & 11892.380 & 1942.817 & 41680.009 & 0.0185 \\
2019 & 33379.670 & 455.988 & 11892.380 & 2494.538 & 48223.056 & 0.0168 \\
2020 & 33419.492 & 524.945 & 11892.380 & 2310.246 & 48147.544 & 0.0167 \\
Average & $60.84 \%$ & $1.28 \%$ & $33.83 \%$ & $4.05 \%$ & $100 \%$ & 0.0406 \\
share & & & & & &
\end{tabular}

36,623.671 gha in 2011 to $48,147.544$ gha in 2020 , with a growth of $31.47 \%$ in ten years. Among the four major activity footprints, the transportation ecological footprint (TEF) accounts for the largest share (60.84\% on average), followed by the tourism activity footprint (ACTEF) $(33.83 \%$ on average), and then the food and fiber consumption ecological footprint (FEF) $(4.05 \%)$ and the accommodation ecological footprint (ACCEF) (1.28\%). It can be seen that the main ecological resource consumption during tourism is the energy consumption from transportation between the residence and the destination and the resource consumption of tourists in Nanyang. The overall per capita ecological footprint (PEF) has been decreasing gradually in the last decade, from 0.0406 gha in 2010 to 0.0167 gha in 2020 , a decrease of $58.8 \%$.

3.4.2. Analysis of the Carrying Capacity of the Tourism Environment. Referring to the environmental carrying capacity calculation method of Monfreda et al, the overall environmental carrying capacity and the per capita environmental carrying capacity of Nanyang City from 2011 to 2020 were calculated according to the land category. From Table 6 it can be seen that as the number of tourists per year 
TABLE 6: Calculation results of the overall environmental carrying capacity and per capita environmental carrying capacity of Nanyang City from 2011 to 2020 .

\begin{tabular}{|c|c|c|c|c|c|c|c|}
\hline Year & $\begin{array}{c}\text { Overall } \\
\text { environmental } \\
\text { commitment carrying } \\
\text { capacity }\end{array}$ & $\begin{array}{c}\text { Environmental } \\
\text { carrying capacity per } \\
\text { capita }\end{array}$ & $\begin{array}{c}\text { Carrying capacity } \\
\text { of agricultural land } \\
\text { per capita }\end{array}$ & $\begin{array}{l}\text { Grassland per } \\
\text { capita carrying } \\
\text { capacity }\end{array}$ & $\begin{array}{c}\text { Forest } \\
\text { carrying } \\
\text { capacity per } \\
\text { capita }\end{array}$ & $\begin{array}{l}\text { Built-up land } \\
\text { carrying } \\
\text { capacity per } \\
\text { capita }\end{array}$ & $\begin{array}{c}\text { Water } \\
\text { carrying } \\
\text { capacity per } \\
\text { capita }\end{array}$ \\
\hline 2011 & 128657.862 & 0.1427 & 0.0036 & 0.0072 & 0.1263 & 0.0055 & - \\
\hline 2012 & 128657.862 & 0.1499 & 0.0038 & 0.0075 & 0.1326 & 0.0058 & - \\
\hline 2013 & 128657.862 & 0.1173 & 0.0030 & 0.0059 & 0.1037 & 0.0045 & - \\
\hline 2014 & 128657.862 & 0.0738 & 0.0019 & 0.0037 & 0.0653 & 0.0028 & - \\
\hline 2015 & 128657.862 & 0.0638 & 0.0016 & 0.0032 & 0.0564 & 0.0024 & - \\
\hline 2016 & 128657.862 & 0.0726 & 0.0018 & 0.0036 & 0.0642 & 0.0028 & - \\
\hline 2017 & 128657.862 & 0.0730 & 0.0018 & 0.0036 & 0.0646 & 0.0028 & - \\
\hline 2018 & 128657.862 & 0.0573 & 0.0014 & 0.0028 & 0.0506 & 0.0022 & - \\
\hline 2019 & 128657.862 & 0.0450 & 0.0011 & 0.0022 & 0.0398 & 0.0017 & - \\
\hline 2020 & 128657.862 & 0.0447 & 0.0011 & 0.0022 & 0.0395 & 0.0017 & - \\
\hline
\end{tabular}

TABle 7: Ecological deficit and Surplus Status of Nanyang City, 2011-2020.

\begin{tabular}{cccc}
\hline Year & Per capita biological carrying capacity (PBC) & Per capita ecological footprint (PEF) & Ecological deficit/surplus \\
\hline 2011 & 0.1427 & 0.0406 & 0.0850 \\
2012 & 0.1499 & 0.0418 & 0.0900 \\
2013 & 0.1173 & 0.0282 & 0.0749 \\
2014 & 0.0738 & 0.0213 & 0.0437 \\
2015 & 0.0638 & 0.0197 & 0.0364 \\
2016 & 0.0726 & 0.0210 & 0.0429 \\
2017 & 0.0730 & 0.0209 & 0.0434 \\
2018 & 0.0573 & 0.0185 & 0.0318 \\
2019 & 0.0450 & 0.0168 & 0.0227 \\
2020 & 0.0447 & 0.0167 & 0.0226 \\
\hline
\end{tabular}

TABLE 8: Ecological stress index and critical value of tourist number carrying capacity in Nanyang City.

\begin{tabular}{lccccc}
\hline & $\begin{array}{c}\text { Number of } \\
\text { visitors }\end{array}$ & $\begin{array}{c}\text { Ecology per capita } \\
\text { footprints (PEF) }\end{array}$ & $\begin{array}{c}\text { Per capita ecological carrying } \\
\text { capacity (PBC) }\end{array}$ & $\begin{array}{c}\text { Ecological } \\
\text { stress } \\
\text { index (EFI) }\end{array}$ & $\begin{array}{c}\text { Safety representation grade } \\
\text { status }\end{array}$ \\
\hline 2020 & 33380351 & 0.016747 & 0.033493 & 0.50 & $2($ safer) \\
EFI $=0.8$ & 52408561 & 0.016747 & 0.020933 & 0.80 & 3 (critical value) \\
\hline
\end{tabular}

increases, the average environmental carrying capacity resources (PBC) per person can be allocated gradually decreases. Therefore, it can be seen that controlling the number of tourists is a key factor for sustainable rural tourism development.

\subsubsection{Ecological Safety Evaluation of Rural Tourism}

(1) Ecological Deficit/Surplus Status. Using the ecological footprint method, the environmental carrying capacity (BC) on the supply side of environmental resources is subtracted from the ecological footprint (EF) on the demand side of environmental resources, and if the value is greater than zero, it is called an ecological surplus; if the opposite is true, it is an ecological deficit.

Combining the data from the overall per capita ecological footprint (PEF) and per capita environmental carrying capacity $(\mathrm{PBC})$ calculations for the four major activity categories in Table 7, the ecological deficit and surplus states were obtained, as shown in Table 7.
According to the calculation results, the ecological carrying capacity of rural tourism in Nanyang City has been in surplus in the past ten years, but the surplus tends to decrease, with the per capita ecological surplus decreasing from 0.085010 gha in 2011 to 0.022633 gha in 2020 , a significant decrease of $73.38 \%$ in ten years. It can be seen that although the environmental carrying capacity of rural tourism is still in surplus, it is still recommended that local governments moderate the development of tourism resources, control the number of tourists, strengthen the publicity of environmental protection, and raise awareness of environmental protection in tourist areas to maintain and improve the current state of ecological surplus.

(2) Ecological Stress Index Status. The results of the calculation of the ecological stress index and the critical value of the carrying capacity of the number of tourists in Nanyang City, using the number of 2020 tourists as the control standard, are shown in Table 8.

As seen from Table 8 , when the number of visitors is 33380351 in 2020, the ecological stress index (EFI) of 
Nanyang City is 0.50 and the ecological safety level is 2 (safer), and when the number of visitors reaches 52408561, the ecological stress index (EFI) of Nanyang City is 0.80 and the ecological safety will reach the critical value.

\section{Conclusions}

\subsection{Research Findings}

(1) The overall transportation ecological footprint of rural tourism has been increasing year by year, from $16,553.39$ gha in 2011 to $33,419.49$ gha in 2020 , with an average annual growth rate of about $10 \%$. This is probably due to the increase in the ecological footprint of transportation caused by tourism transportation energy. To reduce the ecological footprint of tourism transportation, the management of exhaust emissions from cars and other vehicles should be strengthened. It is recommended that local governments develop mass transportation, mainly electric vehicles, to improve traffic pollution.

(2) The overall ecological footprint of rural tourism increased from 36623.671 gha in 2011 to 48147.544 gha in 2020 , an increase of $31.47 \%$ in ten years. Among them, the ecological footprint of transportation is $60.84 \%$, the ecological footprint of tourism activities is $33.83 \%$, the ecological footprint of food and fiber consumption is $4.05 \%$ and the ecological footprint of accommodation is $1.28 \%$. This shows that the ecological pressure from transport and tourism activities is still increasing year by year. In contrast to the overall ecological footprint, the ecological footprint per capita has shown a decreasing trend in the last decade, from 0.0406 gha in 2010 to 0.0167 gha in 2020 , a decrease of $58.8 \%$. The starting reason may be due to the increase in tourism, which dilutes and neutralizes the ecological footprint.

(3) Analysis of the ecological footprint of tourism by land category shows that the productive land with the highest proportion of the overall ecological footprint is built-up land. This indicates that tourists have the highest demand (52.6\%) for services such as public facilities, buildings and dwellings, and activity spaces during their recreation, followed by the carbon footprint emitted from energy consumption $(43.82 \%)$ and a smaller demand for food and fiber consumption produced by forests, agricultural lands, grasslands, and waters.

(4) The study uses the annual incremental number of tourists from 2011 to 2020 as the reference value (7.1\% per year), and the critical value of environmental pressure on rural tourism using the ecological pressure threshold value shows that when the ecological pressure EFI value is 0.5 (safe), the ecological carrying capacity per capita is 0.3349 gha, and when the EFI is 0.8 , the ecological carrying capacity per capita is 0.0209 gha (more safe) shows a decreasing trend.
4.2. Recommendations. Based on the results of the above empirical analysis, the paper proposes to make the following recommendations.

(1) The control of ecological carrying capacity is strengthened, and the formulation of land planning and environmental protection policies is accelerated. On the one hand, the natural environment and the ecological protection system of flora and fauna in Nanyang City should be protected. On the other hand, the control of ecological carrying capacity should be strengthened by enhancing the management of tourists, avoiding their acts of polluting the environment, and promoting energy-saving and environmentally friendly tourism methods and encouraging people to use low-carbon and low-energy-consuming transportation.

(2) The spatial pattern of tourism should be reasonably designed and the distribution of tourism resources should be reasonably distributed. Since the number of tourists has a positive impact on the total footprint of all kinds of activities, the larger the number of tourists, the larger the ecological footprint, and the greater the impact on the environment. Therefore, the tourism management department of Nanyang City should pay full attention to the environmental problems caused by the uneven spatial and temporal distribution of tourists in the city, further strengthen the balanced planning of tourism resources, and effectively divert the flow of tourists through a combination of measures, so as to achieve a reasonable spatial and temporal pattern of tourism.

(3) Tourism resources are developed appropriately, and environmental education and publicity are strengthened. In the past ten years, although the environmental carrying capacity of Nanyang City is in surplus, it shows an obvious downward trend, with the per capita ecological surplus reduced from 0.085 gha in 2011 to 0.0226 gha in 2020 , a decrease of about $73.38 \%$. This indicates that the pressure on the ecological environment of the city is increasing, so it is suggested that the relevant departments should moderate the development of tourism resources, control the number of tourists, and strengthen the environmental education and publicity training for tourists, so as to cultivate their environmental awareness and reduce the negative impact on the ecological environment of rural tourism.

4.3. Limitations. In this paper, the construction of environmental carrying capacity index system is only aimed at rural tourism in Nanyang City (China), which lacks extensive practical verification. The selected indicators are also limited, which cannot achieve comprehensive, and may need further modification and improvement in practical application. 


\section{Data Availability}

The data that support the findings of this study are available from the corresponding author upon reasonable request.

\section{Conflicts of Interest}

The authors declare that they have no conflicts of interest.

\section{Acknowledgments}

This research was funded by the National Social Science Foundation of China (grant no. 20CJY053); Henan Provincial Science and Technology Research Soft Science Project (grant no. 212400410259); and Xinyang Normal University Postgraduate Research Innovation Project in 2020 Fund Project (grant no. 2020KYJJ19)

\section{References}

[1] M. Wider, S. Szewrański, and J. K. Kazak, "Environmental carrying capacity assessment-the policy instrument and tool for sustainable spatial management," Frontiers in Environmental Science, vol. 8, Article ID 579838, 2020.

[2] A. Leka, A. Lagarias, M. Panagiotopoulou, and A. Stratigea, "Development of a tourism carrying capacity index (TCCI) for sustainable management of coastal areas in Mediterranean islands - case study Naxos, Greece," Ocean \& Coastal Management, vol. 216, Article ID 105978, 2022.

[3] D. Zhang, "Research on the development of rural tourism in Nanyang city," New Business Weekly, vol. 5, no. 12, 2017.

[4] Y. Pang, "Analysis of coupling association between rural tourism and rural revitalization in Henan province," China Agricultural Resources and Zoning, vol. 40, no. 11, pp. 315320, 2019.

[5] W. F. LaPage, "Some sociological aspects of forest recreation," Journal of Forestry, vol. 61, no. 1, pp. 32-36, 1963.

[6] M. Wackernagel and W. E. Rees, Our Ecological Footprint: Reducing Human Impact on the Earch, New Society Publishiers, Gabriola Island, Canada, 1996.

[7] B. S. Bhandari and M. Grant, "Analysis of livelihood security: a case study in the Kali-Khola watershed of Nepal," Journal of Environmental Management, vol. 85, no. 1, pp. 17-26, 2006.

[8] M. Wackernagel and J. Silverstein, "Big things first: focusing on the scale imperative with the ecological footprint," Ecological Economics, vol. 32, no. 3, pp. 391-394, 2000.

[9] M. Wackernagel and J. D. Yount, "Footprints for sustainability: the next steps," Environment, Development and Sustainability, vol. 2, no. 1, pp. 23-44, 2000.

[10] L. Wang, "Study on ecological carrying capacity of Henan Province from the perspective of ecological footprint," Resource Development and Market, vol. 33, no. 12, pp. 14561460, 2017.

[11] B. Zhang and X. Liu, "Simulation and prediction of ecological footprint dynamics based on ARIMA model--an example from Gansu province," Journal of Ecology, vol. 21, no. 20, pp. 6251-6260, 2011.

[12] X. Zhu and L. Peng, "Research on fitting and prediction of ecological footprint in Hubei Province based on BP neural network," Journal of Wuhan University of Science and Technology (Social Science Edition), vol. 17, no. 1, pp. 77-80, 2015.

[13] Y. Yang and J. Xu, "Research on sustainable development of tourism in Zhangiajie based on tourism ecological footprint model," Journal of Central South University of Forestry Science and Technology, vol. 25, no. 6, pp. 107-110, 2016.

[14] Z. Zhang, C. Bai, and D. Yang, "Research on sustainable development of tourism in coastal areas of Guangxi based on ecological footprint index," Ecological Economy, vol. 33, no. 6, pp. 100-104, 2017.

[15] P. Martens, J. C. J. H. Aerts, B. Amelung et al., "Imagining the unimaginable: synthesis of essays on abrupt and extreme climate change," Current Opinion in Environmental Sustainability, vol. 10, p. 2, 2010.

[16] S. Gössling, "Global environmental consequences of tourism," Global Environmental Change, vol. 53, pp. 283-302, 2002.

[17] C. Monfreda, M. Wackernagel, and D. Deumling, "Establishing national natural capital accounts based on detailed ecological footprint and biological capacity assessments," Land Use Policy, vol. 21, no. 3, pp. 231-246, 2003. 